\title{
Deep-marine channel deposits of Cotumba-Sita-Tătaru Sandstones, Teleajen Valley, Romania (East Carpathian Flysch Zone)
}

\author{
L'ubomír ŠTRBA \\ Faculty BERG, Technical University of Košice, Letná 9, 04200 Košice, Slovakia
}

Received January 2012; accepted April 2012

Available online 29 May 2012

DOI: $10.5038 / 1937-8602.57 .2 .3$

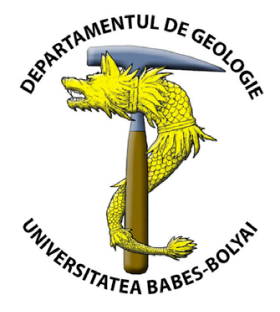

\begin{abstract}
The Cotumba-Sita-Tătaru Sandstones of Teleajen Unit (Upper Aptian - Albian) are relatively well exposed in the Teleajen Valley (Prahova County, Romania), as predominantly thick and massive sandstone beds. Other facies occurring in the study area include sandstones with several sedimentary structures (e.g., parallel lamination, ripples, convolution), siltstones and mudstones. Almost $200 \mathrm{~m}$ long outcrop gives great opportunity for sedimentological study focusing on deep-marine facies and interpretation of exposed deposits. A sedimentological study of the facies and stacking patters suggest that these rocks were deposited in relatively shallow depositional channels with levees and interchannel areas.
\end{abstract}

Key words: East Carpathians Flysch Zone, channel, turbidite, Teleajen, Romania.

\section{INTRODUCTION}

In recent years, as hydrocarbon exploration moved into increasingly deeper waters, the sedimentology of deep-marine clastic deposits has been the focus of a large number of studies. Sandy turbidites are the most common reservoirs, and therefore they become especially important.

The analysis of deep-marine sedimentary systems often relies on identification of architectural elements (e.g., channels, levees, lobes). An outcrop study plays a key role in the process of the submarine fan descritpion (e.g., Bouma and Stone, 2000).

The aim of this work is to characterize deposits and depositional environment of Cretaceous sediments in the area of the Teleajen Valley in Romanian Flysch Zone; $4.5 \mathrm{~km}$ to the NE from MăneciuUngureni (Prahova district; GPS coordinates: $45^{\circ} 20^{\prime} 41^{\prime \prime} \mathrm{N}, 25^{\circ}$ $57^{\prime} 11$ ' E). Based on field research and subsequent interpretation, the sediments were described in terms of: 1) individual facies, 2) facies associations, and 3) depositional setting (e.g., channels, levees).

\section{GEOLOGICAL SETTINGS}

The Eastern Outer Carpathians (Moldavides complex), mainly consisting of Cretaceous and Tertiary flysch and molasse sediments and affected by Tertiary deformation, build a continuous mountain belt convex towards its foreland (Săndulescu, 1975, 1980, 1984; Debelmas et al., 1980). The Moldavides are the outermost unit of the Romanian Carpathians and represent the major part of East Carpathian Flysch Zone. From the inside part of the belt to the outside, the Moldavides comprise following units: Teleajen (also called "Convolute Flysch"), Macla, Audia, Tarcau, Margi- nal Folds and Subcarpathian Nappes. These units represent sedimentary allochtonous formations detached from their basement and overthrusted eastward above the foreland (Săndulescu and Dimitrescu, 2004).

The study area is in the Teleajen Valley, situated in the south-eastern part of central Romania, where sediments of the Teleajen unit crop out (Fig. 1). The Teleajen unit consists of Cretaceous rocks of Upper Aptian to Senonian age. Based on the ammonite Parahoplites aff. melchioris, the lower boundary is thought to belong to the Upper Aptian (Clansayesian). The Upper Aptian - Albian interval includes three formations: Palanca Formation (based on Puzosia mayoriana, Puzosia aff. planulata, Hamites sp., Hoplutes dentatus, Neohibolites minimus, Inoceramus tenuis), Cotumba-Sita-Tătaru Sandstones (based on Puzosia cf. comunis, Anisoceras armatum, Neohibolites minimus, Parahibolites tourtiae) and Aucellina Formation (based on Aucellina grypheoides). Upper Cretaceous sediments are represented by two formations: Teliu-Lutu Rosu Formation (Cenomanian age based on Neohibolites ultimus, Parahibolites tourtiae, Mantelliceras mantelli, Turrilites cf. costatus, Puzosia planulata, Inoceramus crippsi) and Dobărlău Valley Formation (Turonian - Coniacian age based on Inoceramus labiatus, Inoceramus lamarcki, Inoceramus sturmi, Inoceramus inconstans, Inoceramus cf. woodsi, Desmoceras aff. sugata) (Mutihac and Ionesi, 1974; Mutihac, 1990). This study focuses on the sedimentology of the Cotumba-SitaTătaru Sandstones (Fig. 1). Sandstone beds of this formation are 0.5 $\mathrm{m}$ thick in average and can be separated by thin layers of siltstone or sandy mudstone. Coarser material in form of micro-conglomerates and conglomerates is present in $100 \mathrm{~m}$ thick layer(s) within this formation. The thickness of whole formation is $400-700 \mathrm{~m}$ (Mutihac, 1990). 


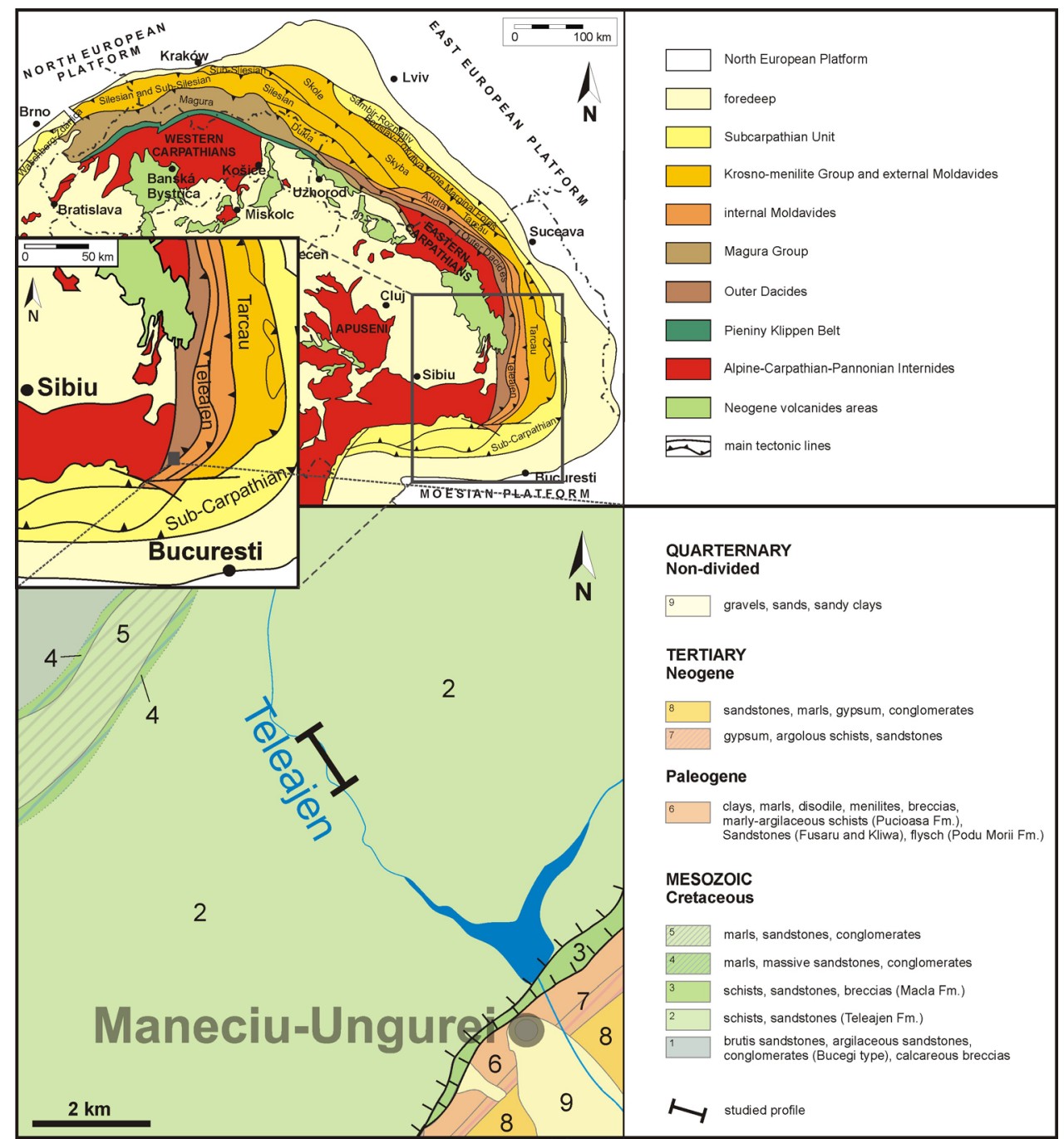

Fig. 1. Location of study area within the Carpathians (after Murgeanu et al., 1968; Kováč et al. in Oszczypko, 2004).

\section{METHODS}

Sedimentological description of outcrops in the Teleajen Valley was the primary data source for this study. Bed thicknesses, sedimentary structures and textures, and lateral extent were recorded for each bed thicker than $1 \mathrm{~cm}$. The total thickness of whole profile is 196 meters. All sediment and bed characteristics were graphically recorded in sedimentary logs.

Subsequent analysis of individual lithofacies recorded during field research and facies associations resulted into the identification of depositional environments in the study area.

There are several approaches to classify and interpret modern and ancient depositional systems. The classification used in this paper is based on the classification of sedimentary successions into hierarchical scheme - elements separated by conspicuous surfaces (Miall, 1985; Mutti and Normark, 1987; Pickering et al., 1995; Stow, 2005).

\section{SEDIMENTARY FACIES}

An alternation of massive sandstones several meters thick with thin-bedded flysch sequences (layers of mostly fine grained sandstone interbedded with mudstone or siltstone layers) is characteristic in the study area (Fig. 2). General strike is NE - SW and NNE - SSE, average dip is $40^{\circ}$. Bed bases often have flute marks. Measurements indicate general paleoflow direction from WNW to ESE. Eight lithofacies types were described (Table 1).

Studia UBB Geologia, 2012, 57 (2), 27 - 34

\section{Facies associations and interpretation}

Based on distribution of facies types, three lithofacies associations were differentiated.

\section{Association A1}

Association A1 represents thick, predominantly massive and/or normally graded sandstone beds, occasionally with parallel lamination in the upper part of an individual layer facies S1, S2 (Fig. 3). Sandstone beds mostly consist of medium to coarse-grained sand, sporadically punctuated by thin mudstone or siltstone interlayers (facies F, C). Granule-sized clasts at the base of beds are common (facies $\mathrm{G}$ ).

Fine-grained sandstones form thinner beds; alternatively, these sandstones occur in the upper part of thicker beds (normal grading). Average thickness of individual beds in this association is 1 to $3 \mathrm{~m}$. Thicker beds are probably products of amalgamation. In some beds, the amalgamation surface is not clearly visible. In general, thick sandstone beds can be divided into two groups:

- mainly massive sandstone beds, with parallel lamination and cross lamination in the upper part (Fig. 4);

- normally graded massive sandstone beds with or without mud-clasts and gravel-sized grains at the base of the layer (Figs. 4 and 5). Thin sequences of parallel and ripple cross lamination in massive sandstone upper parts represent parts of the Bouma sequence (Fig. 6) formed by turbidity currents (Bouma, 1962; Baas, 2004; Mutti et al., 2009). 


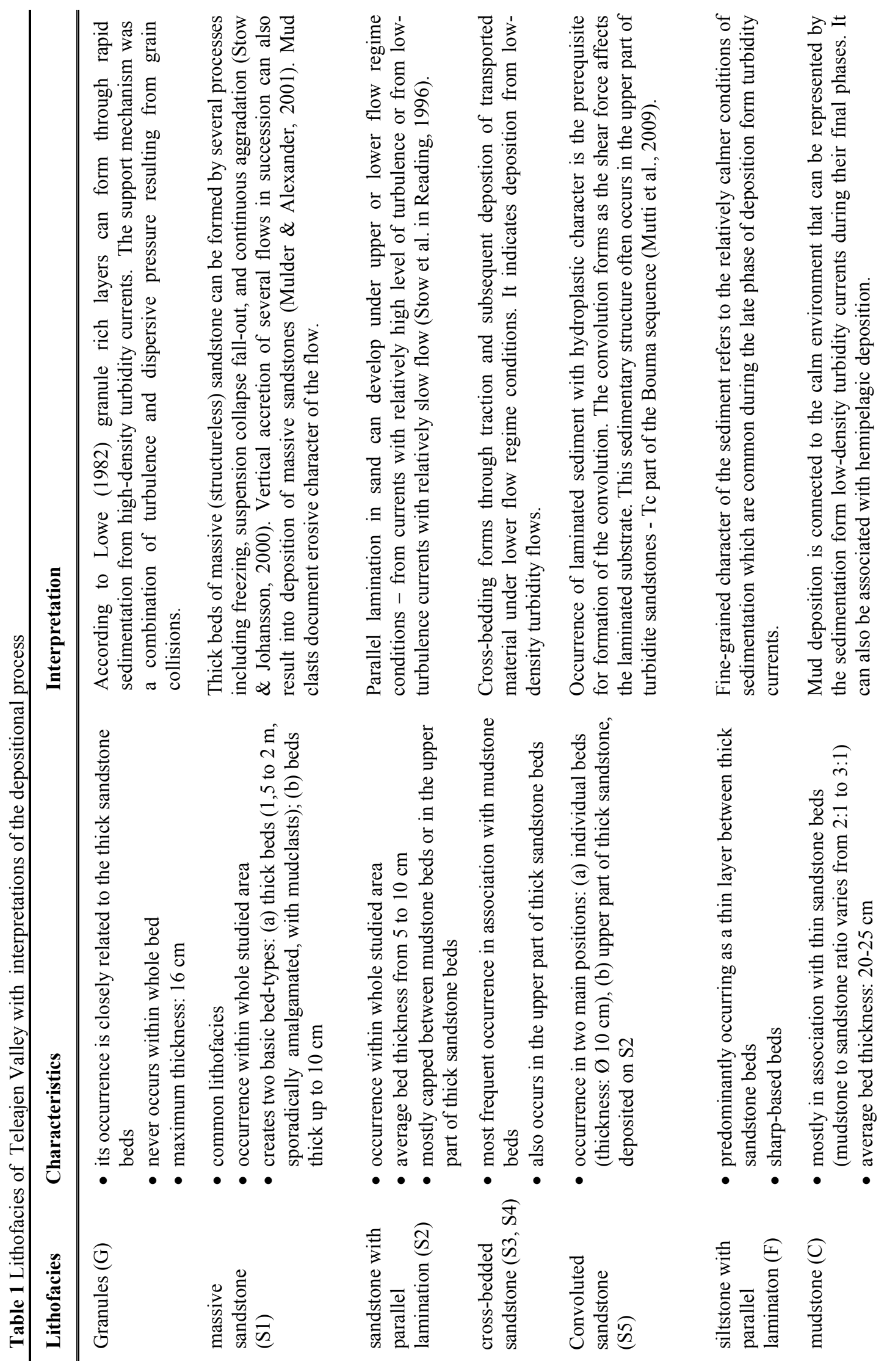



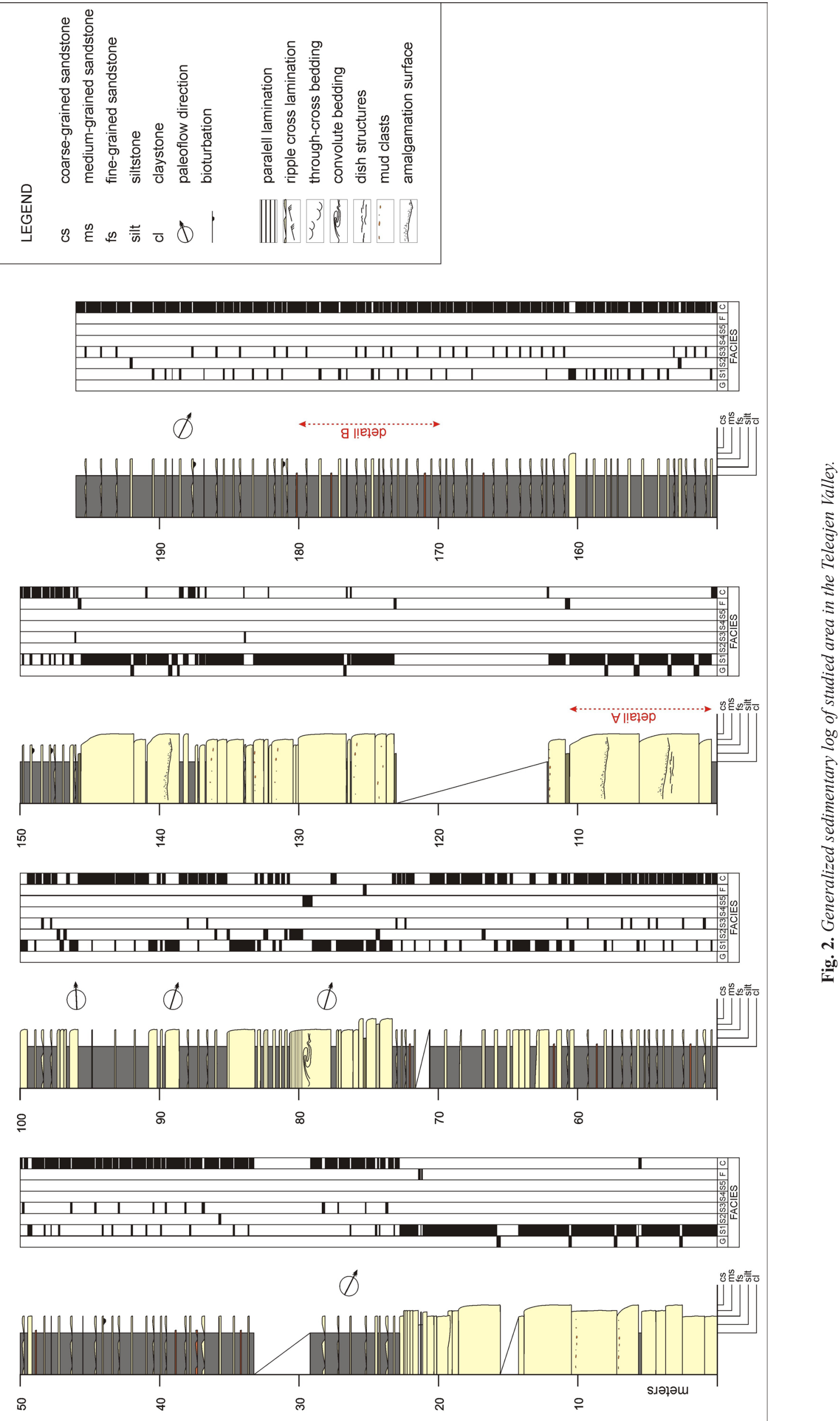


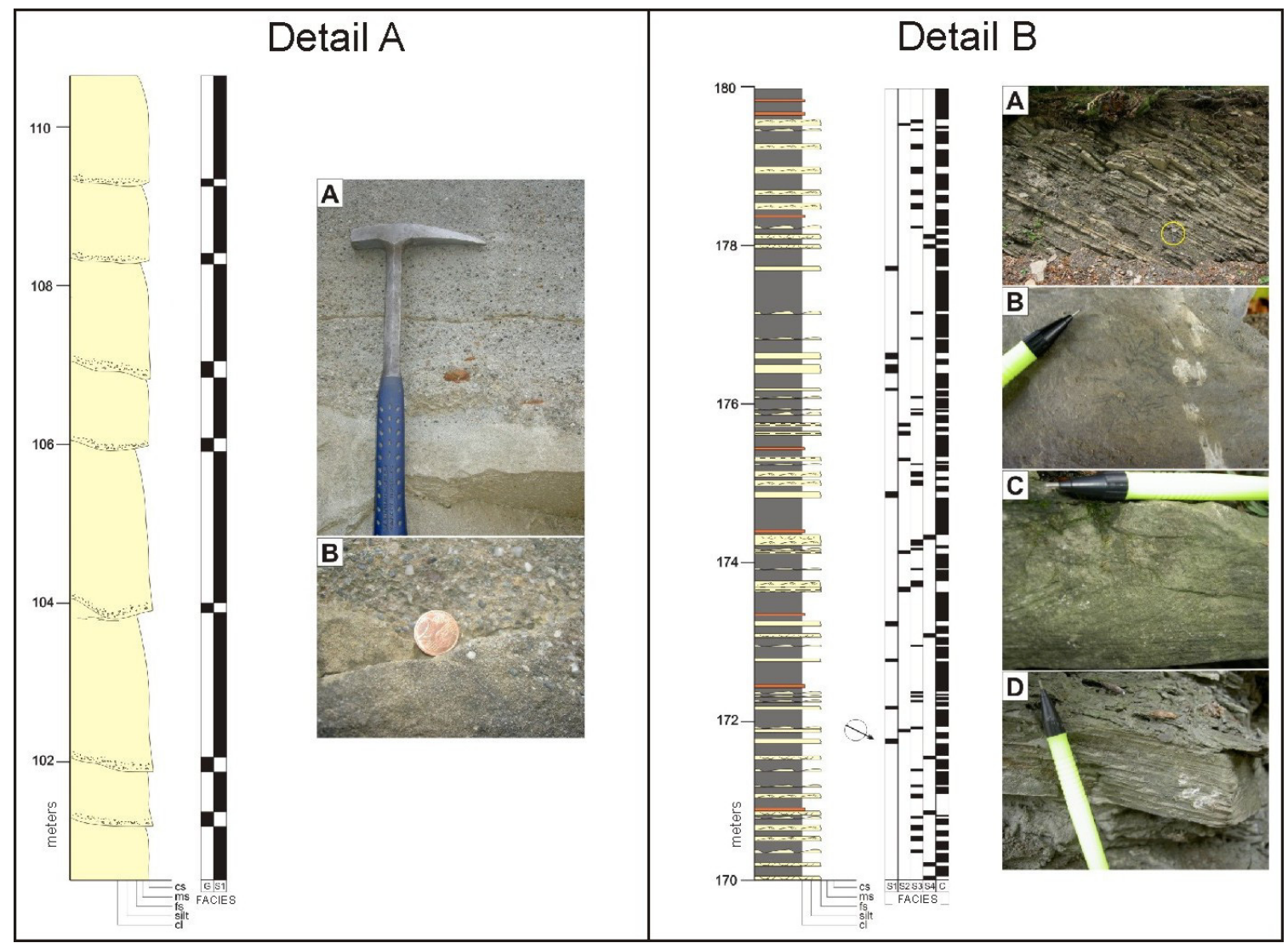

Fig. 3. Detailed logs of individual facial associations. Detail A: facial association A1 (A and B-grain size change within amalgamated thick sandstone bed); Detail B: facial association A3 (A: thin rhythmic alteration of sandstone, siltstone and mudstone beds; geological hammer in yellow circle for scale; B: ichnofossils of Chondrites; $\boldsymbol{C}$ : finegrained sandstone with parallel lamination at the base of the bed with turning to cross-bedding; D: parallel laminated siltstone).

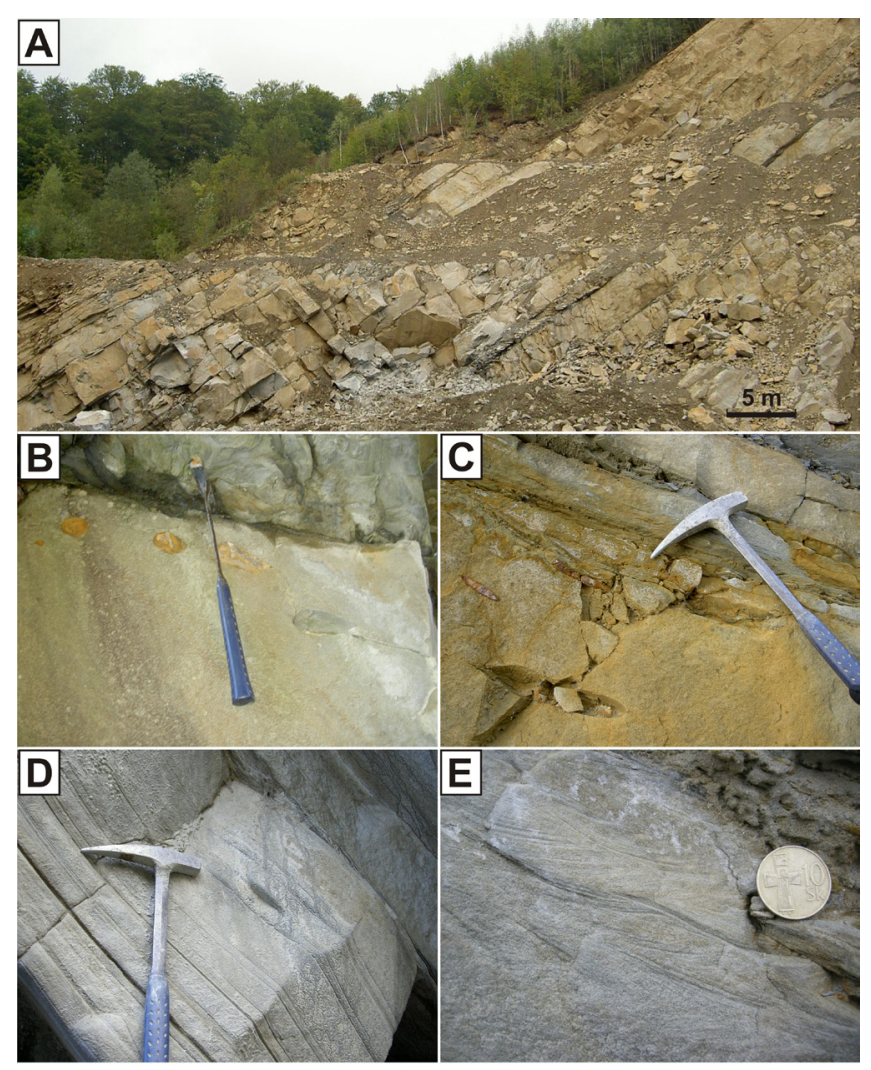

Fig. 4. Features of the Teleajen Valley sandstones. A: massive sandstone beds; B: mudclasts in the upper part of the sandstone bed; $C:$ mudclasts in the upper part of sandstone to siltstone bed; D: sandstone with parallel lamination; $\mathbf{E}$ : upper part of massive sandstone bed with parallel lamination and cross bedding indications (Ta - Tc part of the Bouma sequence).

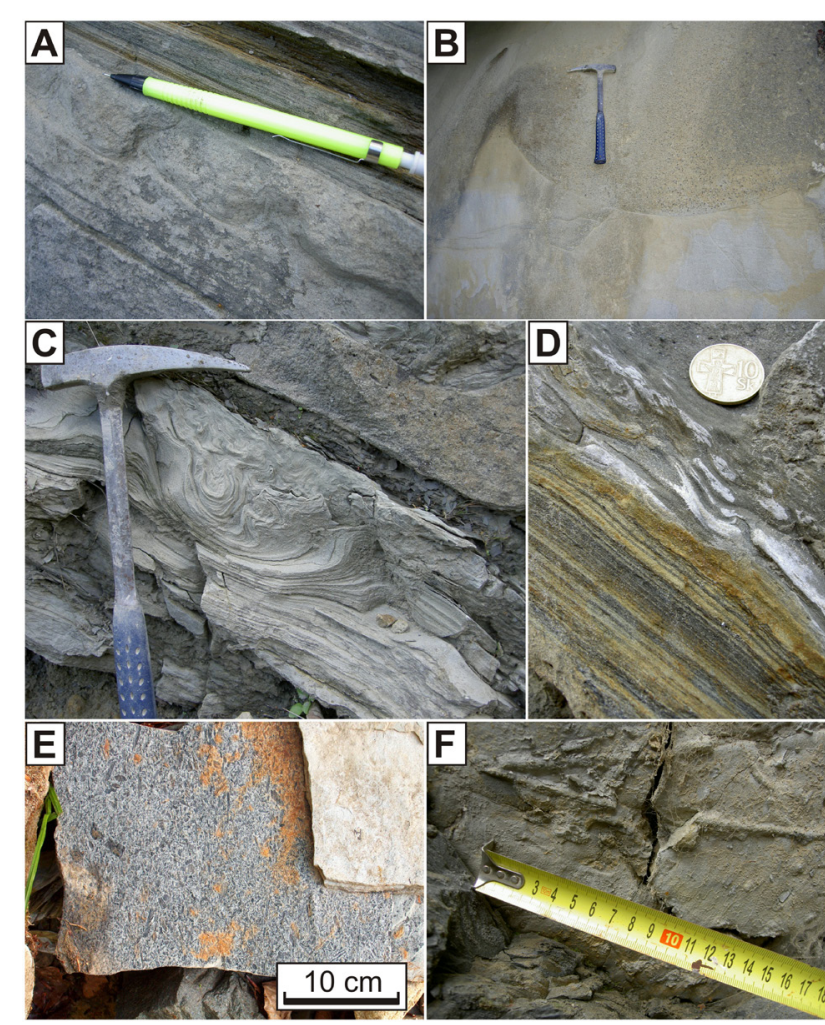

Fig. 5. Features of the Teleajen Valley sediments. A: sandstone with parallel lamination and water escape structures; B: convex scour cut into fine grained sandstone and filled by granulite and coarse grained sandstone; $\boldsymbol{C}$ : transition from parallel laminated sandstone to convoluted sandstone; D: siltstone with parallel lamination; $\boldsymbol{E}$ : carbonized organic remnants within the sandstone bed; $\boldsymbol{F}:$ bioturbation at the base of the sandstone bed (Ophiomorpha).

Studia UBB Geologia, 2012, 57 (2), 27 - 34 
The small number of whole or partial Bouma sequences and the frequent occurrence of normally graded sandstones with mud clasts and/or granule sized quartz clasts could be interpreted as deposition from high-density turbidity currents (Lowe, 1982; Postma, 1986; Postma et al., 1988). These currents represent the transition between low-density turbidites and sandy debris flows. Kneller and Branney (1995) discussed the idea of variable flow character through time. Abrupt changes in grain size or alternation of massive and parallel laminated sandstone can be caused by these temporal changes in the current character.

Mud clasts are mostly ordered in a bedding-parallel line, located 10 to $15 \mathrm{~cm}$ from top of the layer.

\section{Association A2}

Association A2 is characterized by the alternation of thin fine sandstone and mudstone or siltstone beds. Occasionally, coarser sandstones are also present. This association mostly includes S1 and S3, lesser S2, S4, and S5. Average thickness of sandstone and mudstone beds is $10 \mathrm{~cm}$ and $18 \mathrm{~cm}$ respectively, although some mudstone beds reach 60 to 100 $\mathrm{cm}$. Mudstone to sandstone ratio is from 2:1 to 3:1. Beds are sharp-based. Continuous transition from fine sandstone to mudstone was observed in several beds.

Alternation of thin, mostly ripple cross-laminated or convoluted sandstone beds and mudstone beds is typical for the area between distributary channels (overbank sensu Mutti and Normark, 1987). Similar sediments were described by others authors (e.g., Mutti, 1977; Clifton, 1981; Pickering, 1982; Maejima et al., 2006).

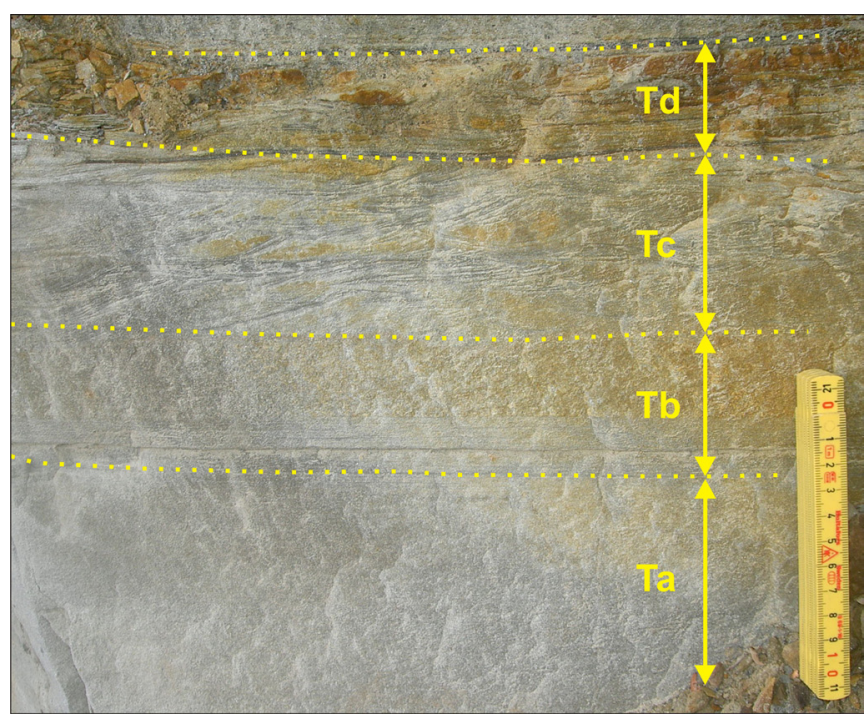

Fig. 6. Sandstone bed from the facial association A1. Ta: massive sandstone; Tb: sandstone with parallel lamination; Tc: sandstone with ripple-cross lamination; $\boldsymbol{T d}$ : siltstone with parallel lamination (classification after Bouma, 1962).

\section{Association A3}

Facies S1, S2, S3, S4, F, and C, mostly as medium thick to thick layers of medium grained sandstone, are characteristic of association A3. The sandstone is often massive or parallel laminated. Individual sandstone beds are deposited directly on each other or they are separated by siltstone or mudstone intercalations. Sandstones are normally graded with coarse-grained sand at the base. Towards to the top of the layer, the sand gradually turns to medium grained, occasionally to fine grained sand. Ripple cross laminated and convoluted sandstones are less common in this association. Other sedimentary features of the association are flute casts and rare shallow scours filled with relatively coarser material. Sporadically, suboval mud clasts $(5 \times 7 \mathrm{~cm})$ are present in the basal part of the layers.

Based on the features of this association and its sediment characteristics it can be assumed that prevailing amount of these sediments was deposited in the channel margin and levee area (Mutti and Normark, 1987, 1991; Stow and Mayall, 2000). Relatively thicker sandstone beds of this association could be deposited during the collapse of a forming levee, when more sand was brought into this area.

\section{DISCUSSION}

The facies associations of the Teleajen Valley were probably deposited on the proximal part of a submarine fan, where distributary channels form. Due to occurrence of amalgamated beds and unclear bed boundaries, it is not possible to specify accurate number of individual channels forming one channel complex. The studied section probably represents three channel complexes (comprising deposits of individual channel thalwegs - association A1) separated by interchannel (association A2) and levee sediments (association A3) (Fig. 7).
1

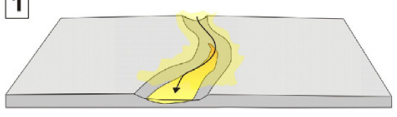

3
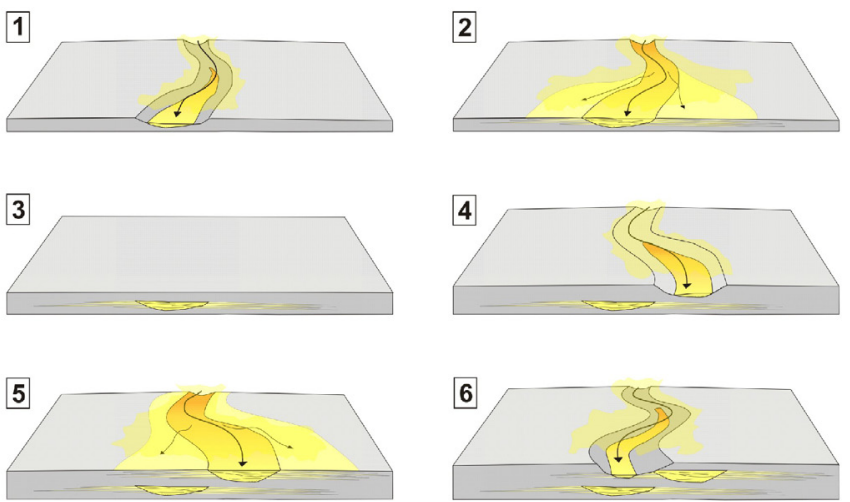
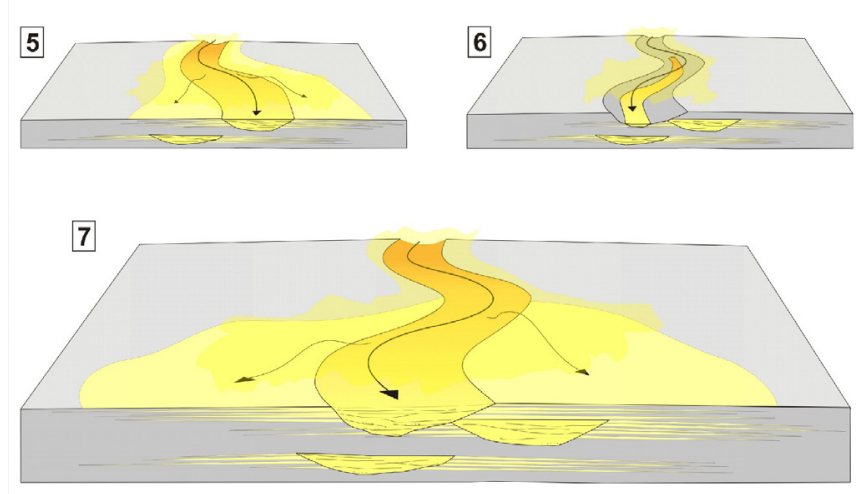

Fig. 7. Diagrams showing the evolution of the channels in the Teleajen Valley area. 1: cutting of the first channel into underlying fine grained sediments; 2: gradual infilling of the channel by sediments and formation of levees; 3: covering of the channel and levee sediments by fine grained thin bedded sediments of intrachannel area and/or hemipelagic sedimentation; 4: cutting of the second channel; 5: gradual infilling of the channel by sediments and formation of levees; 6: cutting of the third channel; 7: infilling of the channel by sediments.

The first channel complex is 23 m thick and mainly consists of massive sandstone. After erosion of this channel complex into the underlying thin-layered fine sediments, the deposition started. The channel was filled by medium to coarse-grained sand (and/or possibly by coarser material in its axial part). Common erosional scours reflect the erosive 
power of the current. This is one of the characteristic features of the channel area.

After this phase, the channel abandonment followed. It is represented by the deposition of the fine-grained interchannel sediments. Thin layers of sandstone, siltstone, and mudstone were deposited during this phase along with intervals of hemipelagic deposition. This resulted in a 38 meters thick sediment succession described as facies association A2 in this paper.

Channel margin and levee sediments, 27 meters thick, belong to the second channel complex and are grouped here in the A3 facies association. Compared with the A1 association, sediments of A3 association are finer, with occasional parallel lamination or ripples.

The most visible channel complex cuts into the channel margin and levee sediments. This complex is $45 \mathrm{~m}$ thick. At its base it has amalgamated beds that consist of gravel and medium-grained sand. Towards to upper parts of this complex, sandstone beds with parallel lamination and/or ripple cross lamination at the top of the bed occur. This reflects the decreasing erosive character of the currents that transported the material into the basin.

Abrupt termination of channel sedimentation probably caused by channel abandonment followed the deposition of this $45 \mathrm{~m}$ thick channel succession. Deposition of fine sediments (mud, silt, fine sand) with different types of bedding, characteristic for the interchannel area, dominated during this time.

Taking into account bed geometries it can be assumed that individual channels that created the channel complexes were relatively wide and shallow with prevalence of massive sandstone beds. Similar channels have been described from Eocene deposits in Spitzbergen (Plink-Bjöklund et al., 2001) or Upper Paleozoic sediments of the Laingsburg Karoo area (Grecula et al., 2003). Using the classification of Mutti and Normark (1987), the deposits exposed in the Teleajen Valley belong to depositional channels.

Erosive power of the currents decreases towards the basin and the channels broaden. The amount of lateral migration of channels depends on the grain size of the transported material (Reading and Richards, 1994; Peakall et al., 2000). Currents transporting finer material often create levees that increase channel stability. Unconsolidated sandy levees are liable to erosion. This can result into frequent shifting of the channel location and formation of sheet-like amalgamated channel deposits (Grecula et al., 2003).

\section{CONCLUSION}

The identification of the type and distribution of architectural elements of deep-marine system (e.g., channels, levees, lobes) is a very important part in the evaluation process of the whole system because it elucidates not only the evolution but also the geometry and related physical parameters of the system. This identification may affect the subsequent evaluation of the system from different viewpoints.

Based on sedimentological outcrop study and subsequent analysis, the Cotumba-Sita-Tătaru Sandstones in the Teleajen Valley consists of 8 litofacies grouped in 3 lithofacies associations. Analysis of these sediments suggests that these are deposits of relatively shallow depositional channels and the associated levees and overbank areas. Three channel complexes were identified. Because the studied outcrop is not big enough to study large-scale geometry, the idea of channellevee deposits is an interpretation of recorded field data.

Knowing and understanding the type of the facies and likely depostional setting of the deposits exposed in the Teleajen Valley contribute to a more complete picture on flysch sedimentation in the Carpathians.

Acknowledgements. The author would like to thank Juraj Janočko, Igor Jurík, Daniela Mihal'ová, and Juraj Oslanec for field assistance, Erika Suciu-Krausz and Ramona Balc for local information and reviewers for their comments which greatly improved the original manuscript. This publication is the result of implementation of the project New detection methods and technologies for exploitation of unconventional energetic Earth resources, ITMS 26220220031 supported by the Research and Development Operational Programme founded by the ERDF.

\section{R E F E R E N C E S}

Baas, J.H. 2004, Conditions for formation of massive turbiditic sandstones by primary sedimentary processes. Sedimentary Geology, 166: 293-310.

Bouma, A.H. 1962, Sedimentology of some flysch deposits. A graphic approach to facies interpretation. Elsevier, Amsterdam, $168 \mathrm{p}$.

Bouma, A.H., Stone, Ch.G. 2000, Fine-grained turbidite systems. AAPG Memoir 72/SEPM Special Publication 68, $342 \mathrm{p}$.

Clifton, H.E. 1981, Submarine canyon deposits, Point Lobos, California. In Upper Cretaceous and Palaeocene turbidites, Central California Coast (Frizelli V., Ed.). Pacific Section, Society of Economic Paleontologists and Mine ralogists, Guide Book to Field Trip, 6: 79-92.

Debelmas, J., Oberhauser, R., Săndulescu, M. \& Trümpy, R. 1980, Alpine-Carpathian arc. In Géologie des chaines alpines issues de la Tethys. $26^{\text {th }}$ International Geological Congress, Paris, Mém B.R.G.M., 115: 86-96 (in French).

Grecula, M., Flint, S.S., De V. Vickens, H. \& Johnson, S.D. 2003, Upward-thickening patterns and lateral continuity of Permian sand-rich turbidite channel fills, Laingsburg Karoo, South Africa. Sedimentology, 50: 831-853.

Kneller, B.C., Branney, M.J. 1995, Sustained high-density currents and the deposition of thick masive sands. Sedimentology, 42: 607-616.

Lowe, D.R. 1982, Sediment gravity flows: depositional models with special reference to the deposits of high-density turbidity currents. Journal of Sedimentary Research, 52: 279-297.

Maejima, W., Hota, R.N. \& Mistra, B. 2006, Turbidite channel and overbank-levee sedimentation of the Permo-Carboniferous Talchir Formation, Talchir Gondwana basin, Orissa, India. Journal of Geosciences, 49: 49-58.

Miall, A.D. 1985, Architectural-element analysis: a new method of facies analysis applied to fluvial deposits. Earth-Science Reviews, 22: 261-208.

Mulder, T., Alexander, J. 2001, The physical character of subaqueous sedimentary density flows and their deposits. Sedimentology, 4: 269-299.

Murgeanu, G., Dumitrescu, I., Săndulescu, M., Bandrabur, I. \& Săndulescu, J. 1968, Romanian Geological Map 1:200000, Covasna Sheet. Romanian Geological Institute, Bucharest. 
Mutihac, V., Ionesi, L. 1974, Geology of Romania. Editura Tehnică, Bucharest, 646 p. (in Romanian).

Mutihac, V. 1990, Geological structure of Romania's territory. Editura Tehnică, Bucharest, 419 p. (in Romanian).

Mutti, E. 1977, Distinctive thin-bedded turbidite facies and related depositional environments in the Eocene Hecho Group (south-central Pyrenees, Spain). Sedimentology, 24: 107-131.

Mutti, E., Normark, W.R. 1987, Comparing examples of modern and ancient turbidite systems: problems and concepts. In Marine clastic sedimentology (Legget, J.K., Zuffa, G.G., Eds.), Graham and Trotman, London, p. 1-38.

Mutti, E., Normark, W.R. 1991, An integrated approach to the study of turbidite systems. In Seismic facies and sedimentary processes of submarine fans and turbidite system (Weimer P., Link, H., Eds.), Springer, New York, p. 75-106.

Mutti, E., Bernoulli, D., Ricci Lucchi, F. \& Tinterri, R. 2009, Turbidites and turbidity currents from Alpine 'flysch' to the exploration of continental margin. Sedimentology, 56: 267-318.

Oszczypko, N. 2004, The structural position and tectonosedimentary evolution of the Polish Outer Carpathians. Przeglad Geologiczny, 52: 780-791.

Peakall, J., McCaffrey, W.D., Kneller, B.C., Stelting, C.E., McHargue T.R., \& Schweller W.J. 2000, A process model for the evolution of submarine fan channels; implications for sedimentary architecture. In Fine-grained turbidite systems (Bouma, A., Stone, C., Eds.), AAPG Memoir 72 SEPM Special Publication, 68: 73-87.

Pickering, K.T. 1982, Middle-fan deposits from the late precambrian kongsfjord formation submarine fan, Northeast Finnmark, Northern Norway. Sedimentary Geology, 33: 79-110.

Pickering, K.T., Hiscott, R.N., Kenyon, N.H., Ricci Lucchi, F. \& Smith, R.D.A. 1995, Atlas of deep water environments, architectural style in turbidite systems. Chapman \& Hall, London, 333 p.
Plink-Björklund, P., Mellere, D. \& Steel, R.J. 2001, Turbidite variability and architecture of sand-prone, deep-water slopes: Eocene clinoforms in the Central Basin, Spitsbergen. Journal of Sedimentary Research, 71: 895-912.

Postma, G. 1986, Classification for sediment gravity-flow deposits based on flow conditions during sedimentation. Geology 14: 291-294.

Postma, G., Nemec, W. \& Kleinspehn, K. 1988, Large floating clasts in turbidites: a mechanism for their emplacement. Sedimentary Geology, 58: 47-61.

Reading, H.G. 1996, Sedimentary environments: processes, facies and stratigraphy ( ${ }^{\text {rd }}$ Ed.), Blackwell Science, Oxford, $688 \mathrm{p}$.

Reading, H.G., Richards, M. 1994, Turbidite systems in deepwater basin margins classified by grain-size and feeder system. AAPG Bulletin, 78: 792-822.

Săndulescu, M. 1975, Paper of structural synthesis of the Carpathians. Bulletin de la Société géologique de France, 17: 299-358 (in French).

Săndulescu, M. 1980, Geotectonic analysis of alpine chains located around western Black Sea. Anuarul Institutului de Geologie si Geofizică, 56: 5-54 (in French).

Săndulescu, M. 1984, Geotectonics of Romania. Editura Tehnică, Bucharest, 334 p. (in Romanian).

Săndulescu, M., Dimitrescu, R. 2004, Geological structure of the Romanian Carpathians, 32 ${ }^{\text {nd }}$ International Geological Congress, Florence, Italy, August 20-28, 2004.

Stow, D.A.V. 2005, Sedimentary rocks in the field. A color guide. Manson Publishing, London, 320 p.

Stow, D.A.V., Johansson, M. 2000, Deep-water massive sands: nature, origin and hydrocarbon implications. Marine and Petroleum Geology, 17: 145-174.

Stow, D.A.V., Mayall, M. 2000, Deep-water sedimentary systems: new models for the $21 \mathrm{st}$ century. Marine and Petroleum Geology, 17: 125-135. 